УДК 616.12-008.331.1-06:616-056.52-053.9

DOI 10.11603/24116-4944.2019.2.10925

(C). Б. Біскупська, І. П. Савченко, Р. Й. Вибирана

Тернопільсъкий національний медичний університет ілені І. Я. Горбачевсъкољо МОЗ України

\title{
ОСОБЛИВОСТІ АРТЕРІАЛЬНОЇ ГІПЕРТЕНЗІЇ У ЖІНОК З МЕТАБОЛІЧНИМ СИНДРОМОМ У ПОСТМЕНОПАУЗАЛЬНОМУ ПЕРІОДІ
}

Мета дослідження - вивчення добового профрілю артеріального тиску (АТ) та виявлення його взаємозв'язків із компонентами метаболічного синдрому (МС) у пацієнток в постменопаузальному періоді.

Матеріали та методи. Обстежено 60 жінок у період постменопаузи. Всіх обстежуваних цієї когорти розподілено на дві групи - з наявністю МС та без нього. У дослідження включено також 30 пацієнток фрертильного віку без ознак менопаузи. Проводили визначення антропометричних даних, добове моніторування АТ (ДМАТ) за допомогою кардіомонітора «Кардіотехніка-4000 АД», біохімічного аналізу крові з вивченням ліпідограми та рівня глюкози.

Результати дослідження та їх обговорення. Аналіз отриманих даних показав, що у пацієнток у постменопаузальному періоді існує взаємозв'язок показників ДМАТ з андроїдним типом перерозподілу жирової тканини, гіпертригліцеридемією та гіперглікемією, що спричиняє негативний вплив на показники АТ і прогноз артеріальної гіпертензії в контексті розвитку ймовірних ускладнень та приєднання ішемічної хвороби серця.

Висновок. У пацієнток у постменопаузальному періоді з МС при ДМАТ реєструються вищі денні, нічні та середньодобові показники як САТ, так і ДАТ, порівняно з хворими без МС; у них виявлено вищі показники навантаження тиском для САТ і ДАТ. У фрертильному віці для жінок характерний сприятливіший перебіг артеріальної гіпертензії (АГ).

Ключові слова: метаболічний синдром; артеріальна гіпертензія; добовий профріль артеріального тиску; постменопаузальний період.

\section{ОСОБЕННОСТИ АРТЕРИАЛЬНОЙ ГИПЕРТЕНЗИИ У ЖЕНЩИН С МЕТАБОЛИЧЕСКИМ СИНДРОМОМ В ПОСТМЕНОПАУЗЕ}

Цель исследования - изучение суточного профиля артериального давления (АД) и выявление его взаимосвязей с компонентами метаболического синдрома у пациенток в постменопаузе.

Материалы и методы. Обследовано 60 женщин в период постменопаузы. Всех обследуемых этой когорты разделено на две группы - с наличием метаболического синдрома (МС) и без него. В исследование включено также 30 пациенток фертильного возраста без признаков менопаузы. Проводили определение антропометрических данных, суточное мониторирование АД (СМАД) с помощью кардиомонитора «Кардиотехника-4000 АД», биохимического анализа крови с изучением липидограммы и уровня глюкозы.

Результаты исследования и их обсуждение. Анализ полученных данных показал, что у пациенток в постменопаузе существует взаимосвязь показателей СМАД с андроидным типом перераспределения жировой ткани, гипертриглицеридемией и гипергликемией, что оказывает негативное влияние на показатели АД и прогноз артериальной гипертензии в контексте развития возможных осложнений и присоединения ишемической болезни сердца.

Вывод. У пациенток с МС в постменопаузе при СМАД регистрируются более высокие дневные, ночные и среднесуточные показатели как САД, так и ДАД по сравнению с больными без МС; у них обнаружены более высокие показатели нагрузки давлением для САД и ДАД. В фрертильном возрасте для женщин характерно более благоприятное течение АГ.

Ключевые слова: метаболический синдром; артериальная гипертензия; суточный профиль артериального давления; постменопаузальный период.

\footnotetext{
FEATURES OF ARTERIAL HYPERTENSION IN WOMEN WITH METABOLIC SYNDROME IN THE POSTMENOPAUSAL PERIOD

The aim of the study - investigation of the daily profile of blood pressure (BP) and identification of its relationship with the components of metabolic syndrome in patients in the postmenopausal period.

Materials and Methods. 60 postmenopausal women were examined. All of these cohorts were divided into two groups - with or without MS. The study also included 30 patients of fertile age without signs of menopause. The anthropometric data were determined, the daily monitoring of blood pressure (DMBP) with the help of cardio monitor "Kardiotehnika-4000 AD", biochemical analysis of blood with analysis of lipidograms and glucose level.

Results and Discussion. The analysis of the obtained data showed that in patients in the postmenopausal period, there is a correlation between indicators of DMBP with android type of redistribution of adipose tissue, hypertriglyceridemia and hyperglycemia, which causes a negative impact on the indicators of blood pressure and the progression of coronary heart disease.

Conclusion. Patients in postmenopausal period with MS with DMBP have higher daytime, nighttime, and daily average rates of both SBP and DBP compared with patients without MS; they found higher pressure load rates for SBP and DBP. In fertile age, women have a more favorable course of hypertension.
}

Key words: metabolic syndrome; hypertension; daily blood pressure profile; postmenopausal period. 
ВстУП. АГ посідає вагоме місце серед усіх загальновідомих факторів ризику серцево-судинних захворювань [4, 20, 21]. За даними Всесвітньої організації охорони здоров'я (ВОО3), у всьому світі тривалість життя жінок у середньому на 4 роки більша, ніж у чоловіків; серед людей похилого віку переважають жінки: частка жінок серед людей у віці 60 років і старшому становить 54 \%, у віці 75 років і старшому - майже $60 \%$, а у віці 90 років і старшому - близько 70 \% [2, 18]. Вивчення гендерних особливостей АГ становить неабиякий інтерес у медичному середовищі, адже це сприятиме спрямуванню розробки необхідних заходів щодо зменшення захворюваності на АГ та її ускладнень, покращення якості життя у різних когортах пацієнтів $[9,18]$. А тим паче, доцільно приділяти більшу увагу вивченню питань АГ у жінок, які перебувають у постменопаузальному періоді [28]. Настання менопаузи залежить від багатьох фракторів: расових, соціальних анатомо-фізіологічних особливостей жінки тощо [13, 24]. В Україні середній вік настання менопаузи становить 48,7 року, тоді як у Європі - 51 рік [27]. У зрілому віці дефіцит статевих гормонів збігається 3 періодом зниження адаптаційних можливостей організму [15] і збільшує ймовірність розвитку остеопорозу [1, 29], ожиріння, цукрового діабету, онкологічної патології [19, 30], атеросклерозу [12], ішемічної хвороби серця [3].

Постменопаузальна АГ характеризується певними особливостями. У цей період частіше діагностується реноваскулярна форма АГ $[5,14]$. Приблизно у 50 \% пацієнток у період постменопаузи відзначається натрійзалежна фрорма АГ $[5,17]$. Підвищення АТ у жінок у постменопаузальний період зумовлено значним підвищенням судинного опору, цьому сприяє також зниження продукції простацикліну, збільшення рівня ендотеліну, зниження ендотеліальнозалежної вазодилатації [8, 11].

Прогресуюча втрата гормональної активності в період менопаузи призводить і до дисбалансу ліпідного спектра: рівня холестерину низької та високої щільності, тригліцеридів, що, в свою чергу, також зумовлює підвищення ризику розвитку серцево-судинних захворювань (СС3) та АГ $[10,6]$.

Підвищення АТ у постменопаузальний період може бути пов'язане і з накопиченням вісцеральної жирової тканини [22] та розглядається як складова менопаузального метаболічного синдрому (МС) [26]. Гіперінсулінемія, що супроводжує менопаузальний МС, сприяє розвитку АГ за рахунок дизелектролітемії (збільшення реабсорбції натрію в нирках, затримка внутрішньоклітинної рідини, підвищення концентрації натрію і кальцію в клітинах гладеньких м'язів артеріол, ремоделювання з потовщенням інтими-медії перифреричних артерій) [2, 23] і зростання перифреричного опору [5, 7, 16]. Інсулінорезистентність у період постменопаузи є ключовим фрактором у фрормуванні порушень вуглеводного і пуринового обміну, ліпідного метаболізму, згортання крові, які залучені у патогенез АГ [8]. Втрата захисних еоректів естрогенів у зв'язку з прогресуючою гіпоестрогенією після настання періоду менопаузи визначає когорту жінок, особливо схильних до підвищення артеріального тиску, з більш тяжким перебігом АГ [25].

МЕТА ДОСЛІДЖЕННЯ - вИвчення ДОбового профрілю AT та виявлення його взаємозв'язків із компонентами метаболічного синдрому в пацієнток у постменопаузальному періоді.
МАТЕРІАЛИ ТА МЕТОДИ. Обстежено 60 жінок у період постменопаузи. Середній вік пацієнток становив $(61,42 \pm 0,69)$ року. Тривалість постменопаузального періоду була у межах $(10,37 \pm 0,67)$ року. У 30 (50 \%) жінок тривалість постменопаузального періоду коливалася від 2 до 5 років, у 8 (13,3 \%) - 6-9 років, у 22 (36,7 \%) - більше 10 років. Всіх обстежуваних цієї когорти розподілено на дві групи - з наявністю МC (n=30, I - основна група) та без нього ( $n=30$, II група, порівняння). В дослідження включено також 30 пацієнток (III група, контрольна) фрертильного віку (в середньому $(50 \pm 0,44)$ року) без ознак менопаузи, тобто за умови відсутності у них непатологічної аменореї або її тривалості до 12 місяців та відсутності прогресуючого десріциту статевих гормонів.

Встановити «метаболічний синдром» дозволяють такі критерії (згідно з ВООЗ та Міжнародною фредерацією 3 цукрового діабету (IDF - International Diabet Federation), 2016 р.):

1. Абдомінальне ожиріння: обвід талії у жінок - більше 80 см; вимірювання зросту і маси тіла з подальшим розрахунком індексу маси тіла (IMT>30 кг/м²).

2. Два з нижченаведених фракторів ризику:

- АТ вище 140/90 мм рт. ст.;

- знижений вміст холестерину ліпопротеїдів високої щільності (ХС лПВГ<1,0 ммоль/л або фракт антиліпідемічної терапії);

- підвищений рівень тригліцеридів (вище 1,7 ммоль/л);

- мікроальбумінурія (вміст альбуміну в сечі 30 мг/дл або відношення альбуміну до креатиніну 30 мг/г);

- інсулінорезистентність (із застосуванням критерію НОМА = інсулін натще $($ мОд/мл) $\times$ глюкоза натще (ммоль/л)/22,5, який в нормі не перевищує 2,77; глікемія венозної крові натще вище 6,1 ммоль/л або порушення толерантності до глюкози з глікемією вище 11,1 ммоль/л через 2 години після навантаження глюкозою).

У пацієнток I і III груп були присутні такі компоненти MC $з$ вищенаведеного, як абдомінальне ожиріння, артеріальна гіпертензія 1-2 ступеня (систолічний AT $\geq 140$ і $\leq 179$ мм рт. ст., діастолічний $A T \geq 90$ і $\leq 109$ мм рт. ст. при офрісному вимірюванні в положенні сидячи або наявність антигіпертензивної терапії на момент включення в дослідження), порушення ліпідограми, в основному за рахунок гіпертригліцеридемії.

Крім визначення IMT, антропометричні дослідження включали вимірювання окружності талії, стегон і відношення окружності талії до окружності стегон як показників, що визначають тип розподілу жирової тканини.

Добове моніторування АТ (ДМАТ) проводили всім пацієнтам протягом 22-24 годин за допомогою кардіомонітора «Кардіотехніка-4000 АД» виробництва ЗАО «Інкарт» (Санкт-Петербург) відповідно до вимог Американської асоціації ДМАТ $[11,12]$. Інтервал між вимірюваннями АТ у денний час дорівнював 15 хв (3 6 до 22 год), у нічний - 30 хв (з 22 до 6 год). Проводили корекцію тимчасових інтервалів активного і пасивного періодів з урахуванням розпорядку дня кожного конкретного пацієнта, при цьому некоректні вимірювання виключили під час попередньої обробки даних. Успішними вважали дослідження при більш ніж 50 якісних вимірюваннях впродовж доби. Аналізували середні цифри систолічного АТ (САТ), діастолічного АТ (ДАТ) і пульсового АТ (пАТ) за денний і нічний періоди, індекси часу гіпертензії і ступінь нічного зниження АТ. 
Проводили визначення біохімічного аналізу крові 3 обов'язковим вивченням: ліпідограми (вміст загального холестерину, тригліцеридів, ліпопротеїдів низької щільності, ліпопротеїдів високої щільності [31] та рівня глюкози - колориметричним методом на автоматичному біохімічному аналізаторі Sapphire-400, Tokio Boek L.T.D. Elitech diagnostics виробництва Seppin S.A.S. (Франція). Рівень імунореактивного інсуліну (IPI) визначали імуноферментним методом за допомогою реактивів фрірми DRG (Німеччина) на автоматичному аналізаторі іEMS Reader MF фрірми ThermoLabsystems (Фінляндія) [9].

Статистичний аналіз результатів проводили за допомогою пакета прикладних програм «STATISTICA for Windows», версія 6.0 із використанням непараметричних методів статистики. Дані представлені у вигляді $(\mathrm{M} \pm \mathrm{m})$, відмінності вважали достовірними при $(p<0,05)$. Оцінку статистичної достовірності відмінностей вибірок проводили з використанням U-критерію Манна-Уїтні та за допомогою кореляційного аналізу з визначенням коефіцієнта лінійної кореляції Пірсона.

РЕЗУЛЬТАТИ ДОСЛІДЖЕННЯ ТА ЇХ ОБГОВОРЕННЯ. Середній вік пацієнток у групах з метаболічним синдромом та без нього достовірно не відрізнявся, складаючи $(61,34 \pm 2,45)$ року в I групі і $(63,27 \pm 2,05)$ року в II групі. Також не було істотних відмінностей за тривалістю АГ в анамнезі при порівнянні обох груп. Тривалість анамнезу АГ коливалася від 13 до 15 років і склала $(13,72 \pm 2,16)$ року в групі з МС і $(12,65 \pm 2,62)$ року в групі без МС. У I групі хворих достовірно вищими були значення окружності талії, що відображають вісцеральне накопичення жирової тканини, складаючи в середньому $(104,22 \pm 7,35)$ см, порівняно 3 $(80,52 \pm 6,24)$ см у II групі $(p<0,01)$. Відношення окружності талії до окружності стегон, збільшення якого (індекс $>0,90$ у чоловіків і >0,80-0,82 у жінок) свідчить про перерозподіл жирової тканини за несприятливим, «андроїдним» типом, у середньому також був вищим у I групі, складаючи $(0,98 \pm 0,04)$ порівняно $з(0,80 \pm 0,02)$ у II групі $(p<0,05)$.

Аналіз даних ДМАТ показав, що у пацієнток з МС вдень, вночі і загалом за добу середні цифрри САТ і ДАТ достовірно вищі, ніж у пацієнток постменопаузального періоду без МС. За результатами низки досліджень виявлено, що середні значення АТ за добу тісно корелюють з ураженням органів-мішеней і прогнозом при АГ [13]. У I групі хворих були достовірно вищі індекси часу гіпертензії для САТ і ДАТ за всі періоди. Для показників пАТ не було виявлено достовірних відмінностей (табл. 1).

Критеріями нормального добового рівня АТ, за даними ДМАТ, вважають 130/80 мм рт. ст. для середнього АТ за добу, 135/85 мм рт. ст. - для середнього АТ вдень і 120/70 мм рт. ст. - для середнього АТ вночі [2]. Згідно 3 цим, у I групі пацієнток денний САТ був підвищений у 16 жінок (53,33 \%), вночі - у 20 (66,67\%), в цілому за добу - у 18 хворих жінок (60\%). У II групі частка пацієнток із підвищеним АТ була майже в 2 рази менша. Так, САТ був підвищеним вдень у 8 обстежених жінок (26,67 \%), вночі - у $10(33,33 \%)$ і за добу в цілому - в 11 пацієнток $(36,67 \%)$ групи порівняння.

Для жінок в період статевої інволюції характерна гіпергідратаційна (об'єм-, натрійзалежна) фрорма артеріальної гіпертензії $[14,15]$. За даними нашого дослідження, підвищення ДАТ також виявлялося значно частіше, ніж САТ. У І групі ДАТ вдень був підвищеним у 18 пацієнток (60\%), вночі - у 14 (46,67 \%), за добу в цілому - у 10 (33,33 \%). Частка обстежених жінок постменопаузального періоду із підвищеним ДАТ у II групі була майже вдвічі меншою: ДАТ був підвищеним вдень у 8 пацієнток $(26,67 \%)$, вночі - у $6(20 \%)$ і в цілому за добу - у 5 хворих жінок $(16,67 \%)$ групи порівняння.

Характерною ознакою АГ у жінок в постменопаузі $\epsilon$ висока варіабельність АТ, особливо САТ [14]. Тому в цієї

Таблиця 1. Показники добового моніторування АТ в обстежуваних пацієнток постменопаузального періоду

\begin{tabular}{||l|c|c|}
\hline \multicolumn{1}{|c|}{ Показник } & І група, $\mathrm{n}=30$ & II група, $\mathrm{n}=30$ \\
\hline САТ доб. сер., мм рт. ст. & $145,65 \pm 3,57$ & $134,66 \pm 2,64^{\star *}$ \\
\hline ДАТ доб. сер., мм рт. ст. & $83,35 \pm 3,43$ & $72,55 \pm 2,36^{\star}$ \\
\hline пАТ доб. сер., мм рт. ст. & $63,62 \pm 2,38$ & $60,44 \pm 2,45$ \\
\hline САТ мм рт. ст. & $149,52 \pm 4,84$ & $138,25 \pm 3,45^{\star}$ \\
\hline ДАТ мм рт. ст. & $85,23 \pm 3,76$ & $74,64 \pm 3,75^{\star \star}$ \\
\hline пАТ мм рт. ст. & $63,35 \pm 2,05$ & $63,36 \pm 2,85$ \\
\hline САТ ніч. сер., мм Рт. ст. & $132,05 \pm 2,72$ & $123,35 \pm 3,43^{\star}$ \\
\hline ДАТ мм рт. ст. & $78,15 \pm 2,05$ & $65,16 \pm 1,55^{\star}$ \\
\hline пАТ ніч. сер., мм рт. ст. & $64,02 \pm 2,62$ & $65,82 \pm 2,45$ \\
\hline Індекс часу САТ доб., \% & $54,32 \pm 1,15$ & $34,45 \pm 1,99^{\star \star}$ \\
\hline Індекс часу ДАТ доб., \% & $25,55 \pm 1,56$ & $11,43 \pm 1,08^{*}$ \\
\hline Індекс часу САТ ден., \% & $47,85 \pm 1,25$ & $33,12 \pm 1,84^{\star}$ \\
\hline Індекс часу ДАТ ден., \% & $23,66 \pm 1,48$ & $12,31 \pm 1,63^{\star *}$ \\
\hline Індекс часу САТ ніч., \% & $64,76 \pm 3,88$ & $41,02 \pm 3,12^{\star *}$ \\
\hline Індекс часу ДАТ ніч., \% & $31,43 \pm 1,57$ & $15,03 \pm 1,07^{*}$ \\
\hline
\end{tabular}

Примітка. Достовірність відмінностей різниці показників у пацієнтів I (основної) і II (порівняння) груп: * - p<0,05; ** - p<0,01. 
групи обстежуваних доцільне застосування індексу часу гіпертензії для оцінки «навантаження тиском». У I групі хворих із МС індекс часу гіпертензії для САТ був підвищеним вдень у 21 пацієнтки (70\%), вночі-у 24 (80\%), за добу - у 22 (73,33 \%) хворих жінок. У II групі цей показник був практично у 2 рази нижчим.

Індекс часу гіпертензії САТ був підвищений вдень у 12 пацієнток (40 \%), вночі - у 13 (43,33\%), за добу - в 11 (36,67 \%) жінок II групи без МС. Підвищення індексу часу гіпертензії ДАТ реєстрували частіше. Зокрема, індекс часу гіпертензії для ДАТ був підвищеним вдень у 11 хворих жінок (36,67\%), вночі - в 10 (33,33 \%), за добу в цілому - у 10 пацієнток (33,33 \%) основної І групи. Підвищення цього параметра в II групі порівняння виявляли в 2,5 рази рідше, ніж в основній I групі хворих з МС.

Достатнє зниження як САТ, так і ДАТ (тип «dipper») у I групі з ожирінням та дисліпідемією реєстрували достовірно рідше, ніж у пацієнток без MC $(p<0,05)$. В I групі переважали хворі жінки в постменопаузі з недостатнім нічним зниженням АТ (тип «nondipper»), тоді як у II групі частка жінок у постменопаузальному періоді без дисметаболічного фону з достатнім зниженням АТ була вищою (рис. 1). Як відомо, відсутність достатнього зниження АТ у нічні години пов'язана з більш високим ризиком розвитку серцево-судинних ускладнень [16].

У I групі частка пацієнток із надмірним зниженням САТ вночі (тип «оverdipper») була дещо меншою, ніж у II групі ( $>>0,05)$. Надмірне зниження АТ у нічні години пов'язують із гіпоперфузією головного мозку і міокарда, особливо при зниженні коронарного резерву [15]. В обох групах були виявлені пацієнтки з підвищенням ДАТ у нічні години (тип «night-peaker»), проте в I групі частка таких жінок була достовірно вищою $(p<0,05)$.

У рекомендаціях Міжнародної групи ВОО3, Міжнародної фредерації з цукрового діабету та рекомендаціях NCEP/ATR III (2016р.), вже починаючи 3 дитячого та підліткового віку, зазначено, що не тільки ожиріння як таке, але і тип перерозподілу жирової тканини в організмі $€$ важливим фрактором розвитку МС. Несприятливим вважають андроїдне (вісцеральне) ожиріння, що характеризується накопиченням жирової тканини в ділянці передньої черевної стінки і оцінюється за величиною окружності талії $[18,25]$. Ми порівняли пацієнток I групи (з МС в постменопаузальному періоді) з хворими на МС жінками фрертильного віку (30 осіб). Аналіз отриманих даних показав, що середні цифри не тільки САТ і ДАТ, але і пАТ вночі і за добу в цілому у хворих із МС у постменопаузальному періоді достовірно вищі. Пульсовий АТ відображає еластичність стінок великих судин, і з його збільшенням понад 53 мм рт. ст. зростає ризик розвитку судинних подій [16]. У III групі середній рівень вночі САТ склав $(129,5 \pm 4,37)$ мм рт. ст., ДАТ - $(69,4 \pm 1,08)$ мм рт. ст., пАТ - $(56,9 \pm 1,28)$ мм рт. ст., у І групі, відповідно, $(158,4 \pm 3,75)(p<0,05) ;(83,3 \pm 2,19)(p<0,05)$ i $(69,6 \pm 2,33)$ мм рт. ст. $(p<0,01)$. Середнє значення за добу САТ у пацієнток з МС фрертильного віку склало $(131,1 \pm 4,15)$ мм рт. ст., ДАТ - $(72,6 \pm 1,31)$ мм рт. ст., пАТ - $(58,4 \pm 1,25)$ мм рт. ст., у хворих із МС у постменопаузальному періоді, відповідно, $(151,6 \pm 4,13)(p<0,05) ;(78,8 \pm 1,76)(p<0,05)$ і $(66,54 \pm 135)$ мм рт. ст. $(p<0,05)$. Індекси часу гіпертензії для САТ і ДАТ були достовірно вищими у пацієнток I групи порівняно 3 хворими на МC III групи.

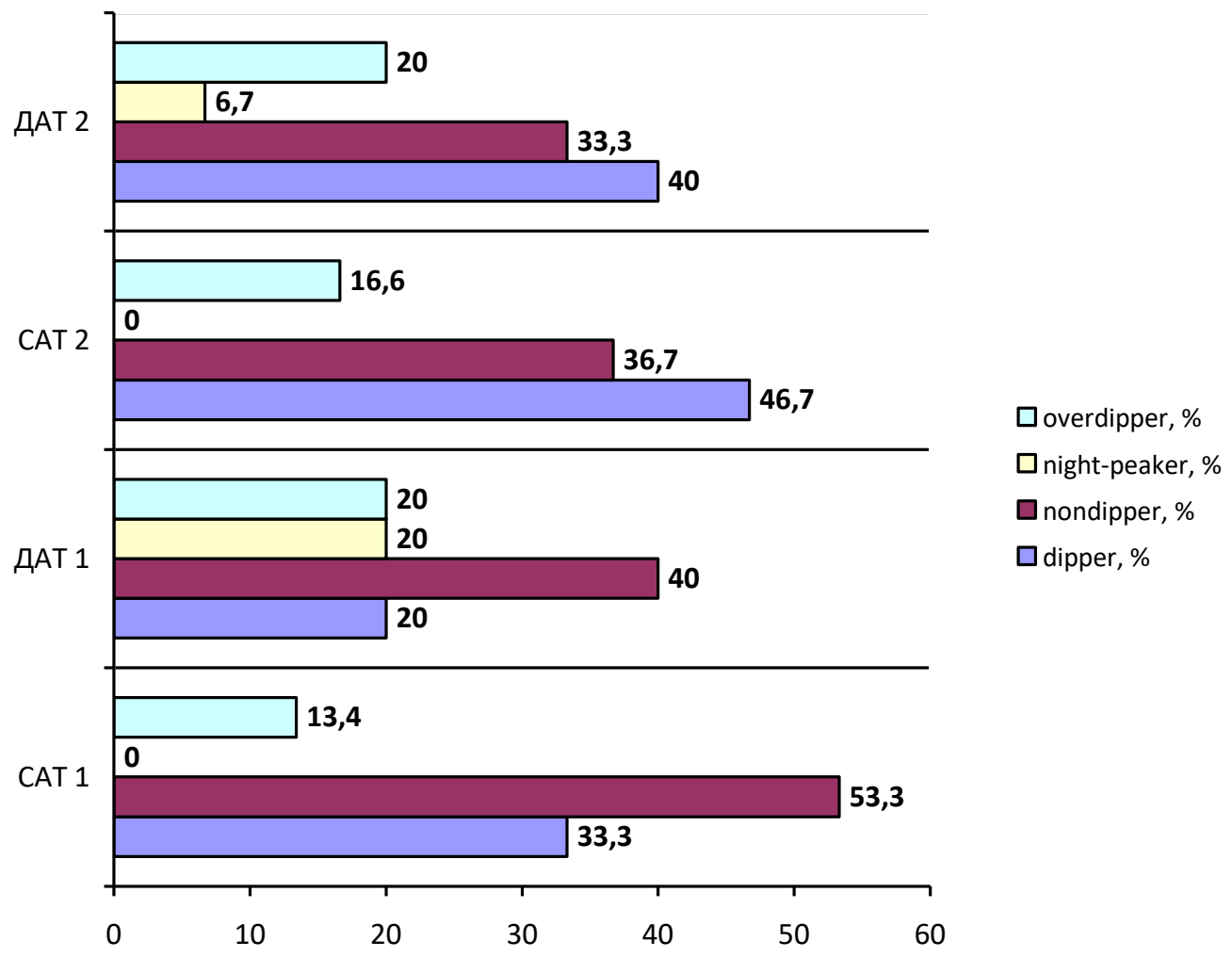

Рис. 1. Розподіл пацієнток у постменопаузальному періоді з метаболічним синдромом (САТ-І і ДАТ-І, n=30) і без нього (САТ-ІІ і ДАТ-ІІ, n=30) залежно від типу добової динаміки АТ. 
Аналіз отриманих результатів показав, що в пацієнток у постменопаузальному періоді існує взаємозв'язок показників ДМАТ з андроїдним типом перерозподілу жирової тканини, гіпертригліцеридемією та гіперглікемією, що спричиняє негативний вплив на показники АТ і прогноз артеріальної гіпертензії в контексті розвитку ймовірних ускладнень та приєднання ішемічної хвороби серця [18, 25].

ВИСновКИ. У пацієнток в постменопаузальному періоді з МС при ДМАТ реєструються більш високі денні, нічні та середньодобові показники як САТ, так і ДАТ, порівняно з хворими без МС; у них виявлено вищі показники навантаження тиском для САТ і ДАТ. Несприятливі типи циркадного профрілю АТ частіше виявляють у жінок із МС. Метаболічний синдром у жінок у постменопаузальному періоді супроводжується більш високими цифррами САТ, ДАТ, пАТ та показниками навантаження тиском порівняно 3 пацієнтками фрертильного віку з метаболічним синдромом.

ПЕРСПЕКТИВИ ПОДАЛЬШИХ ДОСЛІДЖЕНЬ. Подальші дослідження, спрямовані на вивчення особливостей артеріальної гіпертензії при метаболічному синдромі у жінок залежно від репродуктивної здатності, сприятимуть оптимальній корекції виявлених розладів та запобіганню небажаних наслідків цієї недуги.

16. Налетов С. В. Состояние обмена углеводов и липидов у женщин с первичной артериальной гипертензией в постменопаузальном периоде / С. В. Налетов, В. Я. Беренуфо // Вестник неотложной и восстановительной медицины. - 2005. - T. 6, № 2. - С. 354-356.

17. Татарчук Т. Ф. Принципи диференційованого підходу до вибору гестагенів при гормонотерапії клімактеричних розладів / Т. Ф. Татарчук, С. І. Регеда, В. С. Сольський // Нова медицина. - 2005. - № 4 (21). - С. 24-29.

18. An expert opinion from the European Society of Hypertension-European Union Geriatric Medicine Society Working Group on the management of hypertension in very old, frail subjects / A. Benetos, C. J. Bulpitt, M. Petrovic [et al.] // Hypertension. - 2016. - Vol. 67 (5). - P. 820-825.

19. Bhupathiraju S. N. Menopausal hormone therapy and chronic disease risk in the WHI: Is Timing Everything? I S. N. Bhupathiraju, J. E. Manson // Endocrine Practice. -2014. - Vol. 20 (11). - P. 1201-1213.

20. Brunström M. Association of blood pressure lowering with mortality and cardiovascular disease across blood pressure levels: a systematic review and meta-analysis / M. Brunström, B. Carlberg // JAMA Intern. Med. - 2018. - Vol. 178 (1). - P. 28-36.

21. Blood pressure lowering for prevention of cardiovascular disease and death: a systematic review and metaanalysis / D. Ettehad, C. A. Emdin, A. Kiran [et al.] // Lancet. - 2016. Vol. 387 (10022). - P. 957-967.

22. Impact of visceral fat on blood pressure and insulin Sensitivity in hypertensive obese women / A. N. Faria, F. F. Ribeiro, S. R. Filho Gouveia Ferreira, M. T. Zanella // Obes. Re. - 2002. - Vol. 10. - P. 1203-1206.

23. Biochemical screening for nonadherence is associated with blood pressure reduction and improvement in adherence / P. Gupta, P. Patel, B. Štrauch [et al.] // Hypertension. - 2017. Vol. 70 (5). - P. 1042-1048.

24. Impaired glucose tolerance, type 2 diabetes and metabolic syndrome in polycystic ovary syndrome: a systematic review and meta-analysis / L. J. Moran, M. L. Misso, R. A. Wild, R. J. Norman // Hum. Reprod. Update. - 2010. - Vol. 16 (4). P. 347-363. https://doi.org/10.1093/humupd/dmq001.

25. Reproductive hormone levels and anthropometry in postmenopausal women with polycystic ovary syndrome (PCOS): a 21-year follow-up study of women diagnosed with PCOS around 50 years ago and their-age-matched controls / J. Schmidt, M. Brannstrom, K. Landin-Wilhelmsen, E. Dahlgren // J. Clin. Endocrinol. Metab. - 2011. - Vol. 96(7). - P. 21782185. https://doi.org/10.1210/jc.2010-2959.

26. The seventh report of the Joint National Committee on prevention, evaluation, and treatment of high blood pressure / A. V. Chobanian, G. L. Bakris, H. R. Black [et al.] // JAMA. 2003. - Vol. 289 (19). - P. 2560-2572. $-2010 .-256$ c 
27. World Health Organization Statistical Information System 2009 [Електронний ресурс]. - Access mode : www.who.int/ whosis.

28. Індопрес-пріоритетний засіб у лікуванні ізольованої систолічної гіпертензії у жінок в клімактеричному періоді / Ф. А. Звершхановський, Є. З. Доскоч, І. В. Жулкевич, К. О. Калайджан // Вісник наукових досліджень. - 2002. № 3. - С. 117-120.

29. Показники мінеральної щільності кісткової тканини у здорових жителів України (на прикладі Тернопільської області) за результатами двофотонної рентгенівської ден- ситометрії. Повідомлення I: жіноче населення / С. І. Сміян, І. В. Жулкевич, О. М. Масик [та ін.] // Проблеми остеології. - 2000. - № 3, Вип. 4. - С. 9-16.

30. Peculiarities of uterine cavity biocenosis in patients with different types of endometrial hyperproliferative pathology / N. Y. Horban, I. B. Vovk, T. O. Lysiana [et al.] // Journal of Medicine and Life. - 2019. - Vol. 12, Issue 3. - P. 266-270.

31. Zhulkevich I. V. Algorithm for phenotyping hyperlipoproteinemias and its application to the" Elektronika BZ21" microcalculator / I. V. Zhulkevich, S. G. VaǏnshteĭn // Laboratornoe delo. - 1986. - No. 10. - P. 623-625.

\section{REFERENCES}

1. Abusuyeva, Z.A., Strizhova, N.V., \& Berestovaya, N.A. (2005). Postmenopauza i vozrastnyye osobennosti lokalizovannogo osteoporoza [Postmenopause and age-related features of localized osteoporosis]. Akusherstvo i ginekologiya - Obstetrics and Gynecology, 2, 50-52 [in Russian].

2. (2013). Zdorovye devochek i zhenshchin [The health of girls and women]. Informatsionnyy byulleten - Newsletter, 334 Retrieved from: www.who.int/mediacentre/ factsheets/fs334/ru/.

3. Aylamazyan, E.K. (2006). Ginekologiya ot pubertata do postmenopauzy. Prakticheskoye rukovodstvo dlya vrachey [Gynecology from puberty to postmenopause. A practical guide for doctors]. Moscow: Izd. "MEDpress-inform" [in Russian].

4. Arterialna hipertenziia. Standarty nadannia medychnoi dopomohy likariamy pervynnoi lanky [Hypertension. Standards for the provision of care by primary care physicians]. Materialy Nastanovy Yevropeiskoho tovarystva z arterialnoi hipertenzii/ Yevropeiskoho tovarystva kardiolohiv (ESC/ESH) 2018 r. z likuvannia arterialnoi hipertenzii - Guidelines of the European Society of Hypertension / European Society of Cardiology (ESC / ESH) 2018 for the treatment of hypertension]. [in Russian].

5. (2003). Arterialnaya gipertoniia u zhenshchin v postmenopauze [Arterial hypertension in postmenopausal women]. Kruglyy stol. Kardiologiya - Round Table. Cardiology, 4, 88-95 [in Russian].

6. Bart, B.Ya., Benevskaya, V.F., Buvaltsev, V.I., \& Boronenkov, G.M. (2002). Prakticheskiy opyt uspeshnogo primeneniya nebivolola pri lechenii arterialnoy gipertenzii u zhenshchin $\mathrm{v}$ postmenopauze [Practical experience of the successful use of nebivolol in the treatment of hypertension in postmenopausal women]. Kardiologiia - Cardiology, 8, 20-24 [in Russian].

7. Mitchenko, O.I. (2005). Menopauzalnyi metabolichnyi syndrom [Menopausal metabolic syndrome]. Nova medytsyna - New Medicine, 4 (21), 18-23 [in Ukrainian].

8. Volkov, V.I., Strona, V.I., \& Smolkin, I.M. (2005). Dyslipidemii ta porushennia hemostazu u zhinok z ishemichnoiu khvoroboiu sertsia [Dyslipidemias and haemostasis disorders in women with coronary heart disease]. Nova medytsyna - New Medicine, 4 (21), 30-33 [in Ukrainian].

9. Rogoza, A.N., Oshchepkova, Ye.V., Balakhonova, T.V., Zelveyan, P.A., Sergakova, L.M., Buniatyan, M.S., \& Skvortsov, A.V. (2001). Sutochnyy ritm arterialnogo davleniya i sostoyaniye organov-misheney u bolnykh s myagkoy i umerennoy formami gipertonicheskoy bolezni [24-hour rhythm of arterial pressure and state of target organs in patients with soft and moderated forms of hypertonic disease]. Terapevticheskiy arkhiv - Therapeutic Archive, 73, 2, 33-38.

10. Kovalenko, V.M. (2005). Sertsevo-sudynni zakhvoriuvannia u zhinok: pidvodna chastyna aisberhu [Cardiovascular diseases in women: the submarine part of the iceberg]. Nova medytsyna - New Medicine, 4 (21), 12-13 [in Ukrainian].

11. Kudryashova, O.Yu., Zateyshchikov, D.A., \& Sidorenko,
B.A. (1988). Vozmozhnaya rol estrogenov v profilaktike i lechenii ateroskleroza u zhenshchin posle nastupleniya menopauzy [The possible role of estrogen in the prevention and treatment of atherosclerosis in women after menopause]. Kardiologiya Cardiology, 4, 51-58 [in Russian].

12. Kudryashova, O.Yu., Zateyshchikov, D.A., \& Sidorenko, B.A. (1988). Vozmozhnaya rol estrogenov v profilaktike i lechenii ateroskleroza u zhenshchin posle nastupleniya menopauzy [The possible role of estrogen in the prevention and treatment of atherosclerosis in women after menopause]. Kardiologiya - Cardiology, 4, 51-58 [in Russian].

13. Kulakov, V.I., \& Smetnik, V.P. (2001). Rukovodstvo po klimakteriyu [Guide to menopause]. Moscow: Meditsinskoye informatsionnoye agentstvo. [in Russian].

14. Kovalenko, V.M., \& Svishchenko, E.P. (Eds.). (2005). Likuvannia arterialnoi hipertenzii v osoblyvykh klinichnykh sytuatsiiakh [Treatment of arterial hypertension in special clinical situations]. Kamianets-Podilskyi: PP. Moshchak M. I. [in Russian].

15. Manukhin, I.B., Taktarov, V.G., \& Shmeleva, S.V. (2010). Zdorovye zhenshchiny $v$ klimakterii: rukovodstvo [The health of women in menopause: a guide]. [in Russian].

16. Naletov, S.V., \& Berenufo, V.Ya. (2005). Sostoyaniye obmena uglevodov i lipidov u zhenshchin s pervichnoy arterialnoy gipertenziyey $v$ postmenopauzalnom periode [The state of carbohydrate and lipid metabolism in women with primary arterial hypertension in the postmenopausal period]. Vestnik neotlozhnoy $i$ vosstanovitelnoy meditsiny - Bulletin of Emergency and Rehabilitation Medicine, 6, 2, 354-356 [in Russian].

17. Tatarchuk, T.F., Reheda, S.I., \& Solskyi, V.S. (2005). Pryntsypy dyferentsiiovanoho pidkhodu do vyboru hestaheniv pry hormonoterapii klimakterychnykh rozladiv [Principles of a differentiated approach to the selection of gestagens in hormone therapy of menopausal disorders]. Nova medytsyna - New Medicine, 4 (21), 24-29 [in Ukrainian].

18. Benetos, A., Bulpitt, C.J., Petrovic, M., Ungar, A., Agabiti Rosei, E., Cherubini, A., ..., \& Mancia, G. (2016). An Expert Opinion From the European Society of Hypertension-European Union Geriatric Medicine Society Working Group on the Management of Hypertension in Very Old, Frail Subjects. Hypertension, 67 (5), 820-825.

19. Bhupathiraju, S.N., \& Manson, J.E. (2014). Menopausal hormone therapy and chronic disease risk in the WHI: Is Timing Everything? Endocrine Practice, 20 (11), 1201-1213.

20. Brunström, M., \& Carlberg, B. (2018). Association of blood pressure lowering with mortality and cardiovascular disease across blood pressure levels: a systematic review and meta-analysis. JAMA Intern. Med., 178 (1), 28-36.

21. Ettehad, D., Emdin, C.A., Kiran, A., Anderson, S.G., Callender, T., Emberson, J., ..., \& Rahimi, K. (2016). Blood pressure lowering for prevention of cardiovascular disease and death: a systematic review and metaanalysis. Lancet, 387 (10022), 957-967. 
22. Faria, A.N., Ribeiro Filho, F.F., Gouveia Ferreira, S.R., \& Zanella, M.T. (2002). Impact of visceral fat on blood pressure and insulin Sensitivity in hypertensive obese women. Obes. Re., 10, 1203-1206.

23. Gupta, P., Patel, P., Štrauch, B., Lai, F.Y., Akbarov, A., Gulsin, G.S., ..., \& Tomaszewski, M. (2017). Biochemical screening for nonadherence is associated with blood pressure reduction and improvement in adherence. Hypertension, 70 (5), 1042-1048.

24. Moran, L.J., Misso, M.L., Wild, R.A., \& Norman, R.J. (2010). Impaired glucose tolerance, type 2 diabetes and metabolic syndrome in polycystic ovary syndrome: a systematic review and meta-analysis. Hum. Reprod. Update, 16 (4), 347-363.

25. Schmidt, J., Brannstrom, M., Landin-Wilhelmsen, K., \& Dahlgren, E. (2011). Reproductive hormone levels and anthropometry in postmenopausal women with polycystic ovary syndrome (PCOS): a 21-year follow-up study of women diagnosed with PCOS around 50 years ago and their-age-matched controls. J. Clin. Endocrinol. Metab., 96 (7), 2178-2185.

26. Chobanian, A.V., Bakris, G.L., Black, H.R., Cushman, W.C., Green, L.A., Izzo, J.L. Jr, ..., \& Roccella, E.J. (2003). The Seventh Report of the Joint National Committee on Prevention, Evaluation, and Treatment of High Blood Pressure. JAMA, 289 (19), 2560-2572.

27. World Health Organization Statistical Information System 2009. Retrieved from: www.who.int/whosis.
28. Zvershkhanovskyi, F.A., Doskoch, Ye.Z., Zhulkevych, I.V., \& Kalaydzhan, K.O. (2002). Indopres-priorytetnyi zasib u likuvanni izolovanoi systolichnoi hipertenzii u zhinok v klimakterychnomu periodi [Indopress priority in the treatment of isolated systolic hypertension in women in menopause]. Visnyk naukovykh doslidzhen - Bulletin of Scientific Research, 3, 117120 [in Ukrainian].

29. Smiian, S.I., Zhulkevych, I.V., Masyk, O.M., Korylchuk, N.I., \& Babinets, L.S. (2000). Pokaznyky mineralnoi shchilnosti kistkovoi tkanyny u zdorovykh zhyteliv Ukrainy (na prykladi Ternopilskoi oblasti) za rezultatamy dvofotonnoi renthenivskoi densytometrii. Povidomlennia I: zhinoche naselennia [Indicators of bone mineral density in healthy residents of Ukraine (Ternopil region) the results of dual energy X-ray densitometry. Post I: the female population]. Problemy osteolohii - Problems of Osteology, 3, 4, 9-16 [in Ukrainian].

30. Horban, N.Y., Vovk, I.B., Lysiana, T.O., Ponomariova, I.H., \& Zhulkevych, I.V. (2019). Peculiarities of Uterine Cavity Biocenosis in Patients with Different Types of Endometrial Hyperproliferative Pathology. Journal of Medicine and Life, 12, 3, 266-270.

31. Zhulkevich, I.V., \& VaĭnshteĬn, S.G. (1986). Algorithm for phenotyping hyperlipoproteinemias and its application to the" Elektronika BZ-21" microcalculator. Laboratornoe delo, $10,623-625$. 